\title{
UPAYA MENINGKATKAN PRESTASI BELAJAR BAHASA INDONESIA MELALUI PENGGUNAAN MODEL PEMBELAJARAN PAIR CHECK
}

\author{
I Nyoman Sukama \\ SMP Negeri 2 Gianyar \\ Gianyar, Indonesia \\ e-mail: sukamanyoman@gmail.com
}

\begin{abstract}
Abstrak
Tujuan penelitian ini adalah untuk meningkatkan prestasi belajar bahasa indonesia melalui penggunaan model pembelajaran Pair Check pada siswa kelas IX E SMP Negeri 2 Gianyar Semester I Tahun Pelajaran 2017/2018. Penelitian ini adalah penelitian tindakan kelas. Subjek dari penelitian ini adalah siswa kelas IX E semester I tahun pelajaran 2017/2018 di SMP Negeri 2 Gianyar. Sedangkan objek penelitian ini adalah peningkatan prestasi belajar Bahasa Indonesia siswa. Data yang diupayakan untuk diperoleh dikumpulkan dengan tes prestasi belajar. Setelah diperoleh data, lalu dilakukan analisis menggunakan analisis deskriptif. Setelah pelaksanaan tindakan, didapatkan data yang menunjukkan peningkatan yang baik, dari awalnya baru mencapai rata-rata 67,85 , padasiklus I meningkat menjadi 73,00 dan pada siklus II meningkat menjadi 79,00. Dengan perolehan peningkatan hasil tersebut dapat disimpulkan bahwa dengan menerapkan Model Pembelajaran Pair Check dapat meningkatkan prestasi belajar Bahasa Indonesia siswa kelas IX E semester I SMP Negeri 2 Gianyar.
\end{abstract}

Kata kunci: Model Pembelajaran Pair Check, prestasi belajar Bahasa Indonesia

\begin{abstract}
The purpose of this study was to improve the learning achievement of Indonesian language through the use of the Pair Check learning model in class IX E students of Gianyar Public Middle School 2 Semester I of 2017/2018 Academic Year. This research is a classroom action research. The subjects of this study were students of class IX E in the first semester of the 2017/2018 school year in Gianyar 2 Public Middle School. While the object of this research is the improvement of students' learning achievement in Indonesian. The data sought to be obtained is collected by learning achievement tests. After obtaining the data, then the analysis is carried out using descriptive analysis. After the implementation of the action, the data obtained showed a good increase, from the beginning it only reached an average of 67.85 , in the first cycle it increased to 73.00 and in the second cycle it increased to 79.00. With the acquisition of improved results it can be concluded that by applying the Pair Check Learning Model can improve the learning achievement of Indonesian Language students of class IX E in the first semester of Gianyar State Junior High 2.
\end{abstract}

Keywords: Pair Check Learning Model, Indonesian learning achievement. 


\section{Pendahuluan}

Keberhasilan proses pembelajaran lebih banyak ditentukan oleh kemampuan guru dalam mengelola proses pembelajaran tersebut. Kadang ada guru yang disebut pintar tetapi lemah dalam menyampaikan pengetahuan dan pemahaman yang ada dalam dirinya maka tentu proses pembelajaran tidak akan berhasil dengan baik. Kadang ada guru yang disebut tidak terlalu pintar tetapi dalam menyampaikan dan mengelola pembelajaran lebih kreatif dan memahami cara penyampaiannya bisa jadi menyebabkan proses pembelajaran akan berhasil dengan baik. Di antara keduanya tentu yang paling sesuai adalah memiliki kemampuan profesionalisme keguruan dan mampu menyampaikan dengan baik demi terciptanya proses dan tujuan pembelajaran yang diharapkan untuk mampu meningkatkan ketakwaan terhadap Tuhan Yang Maha Esa.

Sehubungan dengan proses pembelajaran yang berlangsung di SMP Negeri 2 Gianyar dari hasil pengumpulan data awal didapat nilai rata-rata siswa kelas 67,85 pada mata pelajaran Bahasa Indonesia baru mencapai $50 \%$. Hasil tersebut tentu tidak sesuai dengan harapan keberhasilan pendidikan yang ditetapkan. Tentang pelajaran yang disampaikan, jika pelajaran sempat diterima peserta didik dan belum berhasil, boleh jadi penyebabnya dikarenakan keterbatasan kemauan guru dalam menerapkan semua keilmuan yang dikuasai demi pencapaian hasil maksimal dalam pembelajaran. Sedangkan dari pihak siswa banyak dipengaruhi oleh kebiasaan belajar mereka yang rendah akibat pengaruh luar, kemampuan ekonomi orang tua dan kebiasaan belajar yang belum banyak dipupuk. Namun apapun yang menjadi latar belakang permasalahan, apabila hal ini dibiarkan berlarut tentu berakibat tidak baik bagi kelangsungan pendidikan peserta didik dan bagi perkembangan mutu pendidikan bangsa Indonesia. Karena hal tersebut di atas merupakan sesuatu yang mendesak untuk dipecahkan menuntut guru lebih kreatif dan inovatif menacari jalan keluar dengan melakukan penelitian yang berguna demi meningkatkan kualitas pendidikan di sekolah.

Melihat kesenjangan antara harapan-harapan yang telah disampaikan dengan kenyataan lapangan sangat jauh berbeda, dalam upaya memperbaiki mutu pendidikan utamanya pada mata pelajaran Bahasa Indonesia, sangat perlu kiranya dilakukan perbaikan cara pembelajaran. Salah satunya adalah perbaikan pembelajaran dengan menggunakan model pembelajaran Pair Check.

Model ini menerapkan pembelajaran kooperatif yang menuntut kemandirian dan kemampuan siswa dalam menyelesaikan persoalan. Model ini juga melatih tanggung jawab sosial siswa, kerja sama, dan kemampuan memberi penilaian (Huda, 2013: 211). Menurut Sanjaya (2007) dijelaskan bahwa, "Pembelajaran Pair Check adalah suatu tipe pembelajaran kooperatif yang berpasangan (kelompok sebangku) yang bertujuan untuk mendalami atau melatih materi yang telah dipelajarinya". Penelitian yang dilakukan oleh lin Benilia Sari et al. (2012) bahwa pemahaman konsep matematis siswa dengan penerapan pembelajaran kooperatif tipe Pairs Check lebih baik daripada pembelajaran konvensional. Menurut Suyatno (2009:72) sintak dari pair check adalah sajian informasi kompetensi, mendemontrasikan pengetahuan dan keterampilan prosedural, membimbing pelatihanpenerapan, pair check siswa berkelompok berpasangan sebangku, salah seorang menyajikan persoalan dan temannya mengerjakan, pengecekan kebenaran jawaban, bertukar peran, penyimpulan dan evaluasi, refleksi. Adapun kelebihan dari pembelajaran kooperatif tipe pair check adalah, a) meningkatkan kemandirian siswa, b) meningkatkan partisipasi siswa untuk menyumbangkan pemikiran karena merasa leluasa dalam mengungkapkan pendapatnya, c). membentuk kelompok lebih mudah dan lebih cepat, d) melatih kecepatan berpikir siswa (Yantiani, 2013)

Model pembelajaran kooperatif tipe Pair Checks adalah salah satu bagian dari model pembelajaran kooperatif. Model pembelajaran kooperatif adalah suatu model pembelajaran dimana sistem belajar dan bekerja dalam kelompok-kelompok kecil yang berjumlah 4-6 orang secara kolaboratif sehingga dapat merangsang siswa lebih bergairah dalam belajar (Isjoni, 2013). Dalam menyelesaikan tugas dalam kelompoknya, setiap anggota kelompok 
harus saling bekerja sama dan saling membantu untuk memahami materi pelajaran. Dalam pembelajaran kooperatif, belajar dikatakan belum selesai jika salah satu anggota kelompok belum menguasai pelajaran. Pembelajaran kooperatif dapat meningkatkan cara belajar siswa menuju lebih baik dan sikap tolong menolong dalam beberapa perilaku social (Puspita, 2018)

Model ini mempunyai langkah-langkah yang mendorong keaktifan siswa dalam belajar dengan cara memberikan kesempatan bagi siswa untuk siap tampil dihadapan temantemannya. Untuk mampu tampil dihadapan orang banyak bukanlah hal yang gampang. Untuk mampu tampil dihadapan orang banyak bukanlah hal yang gampang.Hal itu memerlukan persiapan yang matang. Untuk persiapan yang matang ini, guru memberik kesempatan yang sebanyak-banyaknya, guru memberi kesempatan agar siswa menyiapkan sebaik-baiknya apa yang akan ditampilkan dihadapan siswa-siswa yang lain. Model pembelajaran Pair Check ini mampu merangsang siswa untuk dapat bertanggung jawab terhadap pekerjaannya, menuntut persiapan yang sangat matang, menuntut kemampuan yang matang dalam presentasi, menutut semangat yang tinggi untuk mengikuti pelajaran agar dapat mempersiapkan tampilan yang diharapkan, menuntut sebab akibat dari pelaksanaan diskusi. Contoh sebab akibat tersebut adalah, apabila siswa giat mengikuti pelajaran, akibatnya adalah mampu memberi tampilan yang diharapkan. Siswa akan menjadi aktif akibat diberikan giliran untuk berbicara di depan teman-temannya, yang sudah pasti akan menimbulkan tuntutan-tuntutan kemampuan yang tinggi baik dalam penampilan maupun keilmuan. Tanpa keilmuan yang mencukupi tidak akan mungkin tampilannya akan memuaskan, dalam hal ini siswa tidak bisa sembarangan saja, mereka harus betul-betul mampu menyimpulkan terlebih dahulu apa yang mereka akan bicarakan. Tuntunan langkahlangkah, motivasi, interpretasi yang inovatif dipihak guru akan menentukan keberhasilan pelaksanaan model ini.

Hipotesis yang diajukan pada penelitian ini adalah apabila model pembelajaran Pair Check dilaksanakan dengan maksimal maka dapat meningkatkan prestasi belajar Bahasa Indonesia siswa Kelas IX E SMP Negeri 2 Gianyar semester I tahun pelajaran 2017/2018.

\section{Metode}

Penelitian ini tergolong Penelitian Tindakan Kelas (Classroom Action Research). Menurut Winardi (dalam Agung, 2010:2) Penelitian Tindakan Kelas (PTK) merupakan penelitian yang dilakukan oleh guru di dalam kelasnya melalui refleksi diri, dengan tujuan untuk memperbaiki kinerjanya sebagai guru, sehingga hasil belajar siswa menjadi meningkat. Penelitian tindakan kelas ini akan dilaksanakan dalam beberapa siklus atau daur ulang dari berbagai kegiatan. Setiap siklus terdiri dari perencanaan tindakan, pelaksanaan, observasi/evaluasi dan refleksi.

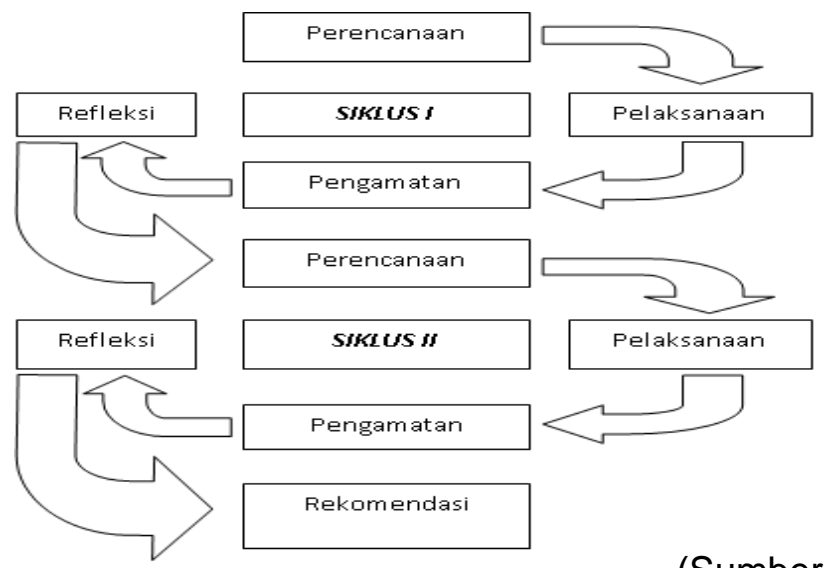

(Sumber: Arikunto, 2008:16).

Gambar 1. Desain Penelitian Tindakan Kelas 
Rancangan penelitian tindakan kelas ini mengacu pada teori Arikunto (2008:16), yaitu "ada empat tahapan pada siklus penelitian diantaranya : 1. Tahap Perencanaan, 2. Tahap Pelaksanaan, 3. Tahap Pengamatan, serta 4. Tahap Refleksi. Metode pengumpulan data yang digunakan dalam penelitian ini adalah metode tes. Metode tes digunakan setelah pembelajaran berlangsung yang berfungsi untuk mengetahui tingkat pemahaman siswa dan dilaksanakan setiap akhir siklus. "Metode tes adalah cara memperoleh data yang berbentuk suatu tugas yang dilakukan atau dikerjakan oleh seseorang atau sekelompok orang yang dites, dan dari hasil tes tersebut dapat menghasilkan suatu data berupa skor" (Agung, 2005:59). Indikator yang digunakan dalam tes disesuaikan dengan kompetensi dasar yang sedang dipelajari. Hasil dari tes adalah kontribusi antara nilai laporan pengamatan, tes yang dilaksanakan pada setiap pertemuan, dan tes pada akhir siklus.

Berpedoman pada metode pengumpulan data tersebut, maka instrumen pengumpulan data yang digunakan dalam penelitian ini adalah tes hasil belajar Bahasa Indonesia. Setelah data dalam penelitian ini terkumpul, maka selanjutnya dilakukan analisis data dengan menggunakan metode analisis statistik deskriptif. Metode analisis statistik deskriptif adalah cara mengolah data dengan jalan menyusun dan menghitung: 1. Skor ratarata (Mean), 2. Median (Me), 3. Modus (Mo) (Agung, 2005).

\section{Hasil dan Pembahasan}

1) Hasil yang diperoleh dari kegiatan awal:

Deskripsi yang dapat disampaikan untuk perolehan data awal sebagai indikator yang dituntut yaitu minimal siswa mampu mencapai ketuntasan belajar dengan nilai sama atau melebihi KKM. KKM yang dipatok berdasarkan ketentuan yang disepakati oleh dewan Guru dan Komite untuk mata pelajaran Bahasa Indonesia adalah 75,00. Data yang diperoleh menunjukkan hanya 18 orang siswa yang tuntas diantaranya 0 orang yang melampaui KKM dan 18 orang setara dengan KKM, secara klasikal jumlah nilai diperoleh adalah 2375 dengan rata rata kelas adalah 67,85 atau hanya $51,42 \%$ yang tuntas dari siswa dikelas IX E pada semester I tahun pelajaran 2017/2018. Data tersebut menunjukkan rendahnya prestasi belajar siswa kelas IX E pada proses pembelajaran awal. Kekurangan yang ada adalah akibat pembelajaran yang dilukan masih bersifat konfensional, kurang alat peraga dan kurang inovatif. Kelebihannya adalah peneliti sebagai guru telah giat melakukan pembelajaran secara maksimal

\section{2) Hasil pada siklus I:}

Perkembangan kemampuan siswa pada siklus I adalah hanya 27 siswa atau $77,14 \%$ yang memperoleh nilai sesuai atau melebihi dengan KKM di sekolah ini. Sedangkan yang lainnya yang berjumlah 8 siswa atau 22,85\% belum mampu mencapai KKM yang dituntut. Data tersebut menunjukkan siswa-siswa tersebut belum giat dalam mengikuti proses pembelajaran oleh karena itu peneliti harus lebih giat lagi melakukan pembelajaran pada siklus berikutnya.

\section{3). Pada siklus II ,}

Perkembangan keilmuan siswa pada siklus II ini adalah dari 35 siswa yang diteliti ternyata hasilnya sudah sesuai dengan harapan yaitu dengan perolehan rata-rata kelas 79,00 . Dari perkembangan tersebut diketahui hampir semua siswa telah mampu mengikuti pembelajaran dengan baik.

Semua hasil yang diperoleh dari awal, siklus I dan siklus II digambarkan dalam bentuk tabel dan grafik seperti berikut: 
Tabel 1 : Tabel Data Hasil Belajar Siswa kelas IX E SMP Negeri 2 Gianyar

\begin{tabular}{|c|c|c|c|c|}
\hline DATA & AWAL & SIKLUS I & SIKLUS II & VARIABEL \\
\hline Skor Nilai & 2375 & 2555 & 2765 & \multirow{3}{*}{$\begin{array}{l}\text { Hasil Belajar } \\
\text { Bahasa Indonesia } \\
\text { Dengan } \\
\mathrm{KKM}=75\end{array}$} \\
\hline Rata Rata Kelas & 67,85 & 73,00 & 79,00 & \\
\hline Persentase Ketuntasan & $51,42 \%$ & $77,14 \%$ & $100 \%$ & \\
\hline
\end{tabular}

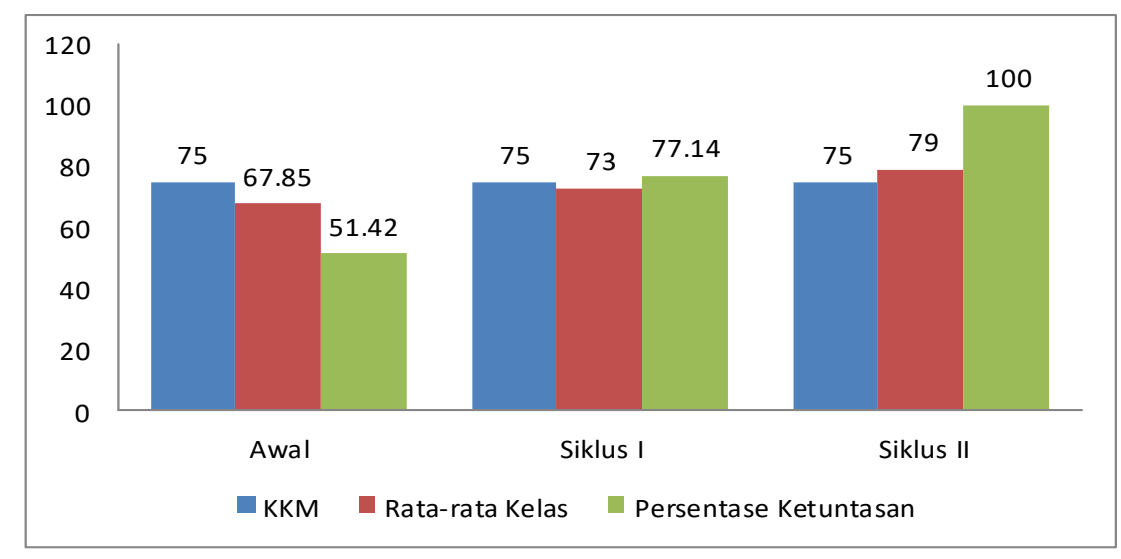

Gambar 1. Grafik Histogram Hasil Belajar Bahasa Indonesia siswa kelas IX E semester I tahun pelajaran 2017/2018 SMP Negeri 2 Gianyar

Data awal yang diperoleh dengan rata-rata 67,85 menunjukkan bahwa kemampuan siswa dalam mata pelajaran Bahasa Indonesia masih sangat rendah mengingat kriteria ketuntasan belajar siswa untuk mata pelajaran ini di SMP Negeri 2 Gianyar adalah 75. Dengan nilai yang sangat rendah seperti itu maka peneliti mengupayakan untuk dapat meningkatkan prestasi belajar siswa menggunakan Model Pembelajaran Pair Check. Akhirnya dengan penerapan Model Pembelajaran Pair Check yang benar sesuai teori yang ada, peningkatan rata-rata prestasi belajar siswa pada siklus I dapat diupayakan dan mencapai rata-rata 73,00. Namun rata-rata tersebut belum maksimal karena hanya 7 siswa memperoleh nilai di atas KKM, 20 orang siswa memperoleh nilai standar KKM, sedangkan yang lainnya belum mencapai KKM. Sedangkan prosentase ketuntasan belajar mereka baru mencapai $77,14 \%$. Hal tersebut terjadi akibat penggunaan Model Pembelajaran Pair Check belum maksimal dapat dilakukan disebabkan penerapan metode tersebut baru dicobakan sehingga guru masih belum mampu melaksanakannya sesua alur teori yang benar.

Pada siklus ke II perbaikan prestasi belajar siswa diupayakan lebih maksimal dengan peneliti membuat perencanaan yang lebih baik, menggunakan alur dan teori dari Model Pembelajaran Pair Check dengan benar dan lebih maksimal. Peneliti giat memotivasi siswa agar giat belajar, memberi arahan-arahan, menuntun mereka untuk mampu menguasai materi pelajaran pada mata pelajaran Bahasa Indonesia lebih optimal. Akhirnya dengan semua upaya tersebut peneliti mampu meningkatkan prestasi belajar siswa pada siklus II menjadi rata-rata 79,00 . Upaya-upaya yang maksimal tersebut menuntun kepada penelitian bahwa Model Pembelajaran Pair Check mampu meningkatkan prestasi belajar Bahasa Indonesia siswa kelas IX E SMP Negeri 2 Gianyar semester I tahun pelajaran 2017/2018.

Hasil penelitian ini sejalan dengan penelitian yang telah dilakukan oleh Lestari (2012) yang berjudul Penerapan Model Pembelajaran Kooperatif Tipe Pair Checks Pemecahan Masalah Untuk Meningkatkan Social Skill Siswa. Hasil penelitiannya adalah Social Skill siswa dari siklus I ke siklus II mengalami peningkatan. Hal ini didapatkan dari data angket skala sikap siklus I ke siklus II ketuntasan klasikalnya meningkat dan sebagian besar siswa sudah memiliki social skill yang baik. Hasil belajar kognitif siswa juga mengalami peningkatan. 
Model pembelajaran kooperatif tipe Pair Checks pemecahan masalah dapat meningkatkan social skill siswa.

Penelitian yang dilakukan Zaenab (2017) yang berjudul Penerapan Model Pair Checks Untuk Meningkatkan Prestasi Belajar IPS Kelas VI. Hasil penelitian menunjukkan adanya eningkatan prestasi beajar IPS setelah menggunakan model ini. Anak yang memenuhi KKM telah melebihi angka ketuntasan kelas

\section{Simpulan dan Saran}

Simpulan pada penelitian ini adalah sebagai berikut.

1) Perolehan data awal yang rendah dan belum mencapai nilai kriteria ketuntasan minimal sesuai harapan, membuat peneliti harus giat mengupayakan cara agar masalah pembelajaran yang ada dapat diperbaiki sehingga peningkatan kemampuan peserta didik dalam menempa ilmu pengetahuan dapat meningkat sesuai harapan,

2) Setelah dilakukan penggantian metode pembelajaran dari model pembelajaran yang konvensional menjadi model pembelajaran yang konstruktivis yaitu Model Pembelajaran Pair Check ternyata hasil yang diperoleh meningkat dari data awal rata-rata 67,85 menjadi 73,00 pada siklus I. Setelah perlakuan tindakan dilakukan dengan cukup intentis maka hasil yang diperoleh pada siklus II naik menjadi 79,00 dan mencapai rata-rata sesuai kriteria ketuntasan minimal yang diharapkan, dan

3) Dengan terjadinya kenaikan prestasi belajar sesuai harapan maka dapat disampaikan bahwa rumusan masalah dan tujuan penelitian sudah mampu meningkatkan prestasi belajar. Dari perolehan bukti tersebut dapat disimpulkan juga bahwa hipotesis penelitian yang diajukan sudah dapat diterima.

Saran perlu disampaikan kepada berbagai pihak atau stake holder pendidikan baik guru, kepala sekolah, pengawas sekolah, Dinas Pendidikan maupun yang lain merupakan bagian dari pihak-pihak yang bertanggung jawab terhadap pendidikan. Saran utamanya dideskripsikan berdasarkan kelemahan-kelemahan penelitian yang masih perlu ditingkatkan serta kelebihan yang perlu di kembangkan.

Sesuai dengan simpulan dari hasil penelitian, dalam upaya mencapai tujuan pembelajaran dalam bidang studi Bahasa Indonesia, dapat disampaikan saran-saran sebagai berikut: 1) Kepada teman guru pengajar mata pelajaran Bahasa Indonesia disarankan mencoba Model Pembelajaran Pair Check, 2) Kepada Kepala Sekolah disarankan untuk untuk memberi penekanan agar guru mau melaksanakan pembelajaran dengan langkah-langkah metode yang sudah diteliti, 3) Dalam melaksanakan proses pembelajaran pada mata pelajaran Bahasa Indonesia, penggunaan Model Pembelajaran Pair Check semestinya menjadi pilihan dari beberapa metode yang ada mengingat metode ini telah terbukti dapat meningkatkan kerjasama, berkreasi, bertindak aktif, bertukar informasi, mengeluarkan pendapat, bertanya, berdiskusi, berargumentasi dan lain-lain, dan 4) Walaupun penelitian ini sudah dapat membuktikan efek utama dari Model Pembelajaran Pair Check dalam meningkatkan prestasi belajar, sudah pasti dalam penelitian ini masih ada hal-hal yang belum sempurna dilakukan, oleh karenanya kepada peneliti lain yang berminat meneliti topik yang sama untuk meneliti bagian-bagian yang tidak sempat diteliti.

Demi kesempurnaan penelitiaan ini, peneliti mengharapkan kritik, saran, masukan yang konstruktif sehingga diharapkan bagi peneliti lain untuk melakukan penelitian lanjutan.

\section{Daftar Rujukan}

Agung, A.A. Gede. 2005. Metodologi Penelitian Pendidikan. Singaraja: STKIP Singaraja.

Agung, A.A. Gede. 2010. Metodologi Penelitian Pendidikan. Singaraja: Universitas Pendidikan Ganesha. 
Ahmad Fandi. 2016. Penerapan Model Pembelajaran Kooperatif Tipe Pair Checks Dalam Meningkatkan Motivasi dan Hasil Belajar IPA Tepadu Siswa Kelas VIIIA SMP Negeri 1 Tabulahan Kab. Mamasa. Jurnal Sainsmat, September 2016, Halaman 137-142 Vol. V, No. 2.

Arikunto, S., dkk. 2015. Penelitian Tindakan Kelas. Jakarta: Bumi Aksara.

Huda, Miftahul. 2013. Model-model Pengajaran dan Pembelajaran Isu-isu Metodis dan Paradigmatis. Yogyakarta: Pustaka Belajar.

Isjoni. 2013. Cooperatif Learning. Bandung: Alfabeta

In Benilia Sari, Rahmi, dan Yulia Haryono. 2012. Pengaruh Penerapan Pembelajaran Kooperatif Tipe PairChecks terhadap Pemahaman Konsep Matematis Siswa Kelas VIII SMPN 3 Batang Kapas Kabupaten Pesisir Selatan. Jurnal Mahasiswa Prodi Pendidikan Matematika STKIP PGRI Sumber, vol.1, no.5.

Kurniawan, Ade. 2017. "Pengaruh Model Pembelajaran Pair Check Terhadap Hasil Belajar PKn Siswa Kelas V SD N 1 Metro Timur". Jurnal FKIP Universitas Lampung, Volume 6, Nomor 6 (hlm.23-24). (diakses pada tanggal 3 Januari 2018).

Lestari dan Linuwih. 2012. Penerapan Model Pembelajaran Kooperatif Tipe Pair Checks Pemecahan Masalah Untuk Meningkatkan Social Skill Siswa. Jurnal Pendidikan Fisika Indonesia 8 (2012) 190-194 Unnes.

Nusantari,dkk. 2008. Peningkatan Keterampilan Belajar Biologi Melalui Model Kooperatif Tipe Pair Checks Siswa Kelas II SMPN 2 Gorontalo. Jurnal Pendidikan Dan Pembelajaran, Volume 15, Nomor 1.

Puspita, I G. A. Ayu Putu Dina, I Kt. Adnyana Putra, I Km. Ngurah Wiyasa. 2018. Pengaruh Model Pembelajaran Kooperatif Tipe Pair Checks Terhadap Penguasaan Kompetensi Pengetahuan IPS Siswa Kelas Iv Sd Gugus li Kuta Selatan Tahun Ajaran 2017/2018. Indonesian Journal of Educational Research and Review, Vol. 1 No. 1

Putri Ayu Widiadnyani. 2014. Pengaruh Model Pembelajaran Pair Cheks Berbantuan Media Lingkungan Hidup terhadap Hasil Belajar IPA Kelas V SDN 5 Pedungan Tahun Ajaran 2013/2014. http://download.portalgaruda. org/article.php?article=138710\&val=1342 diakses pada tanggal 18 Februari 2017.

Sanjaya, Wina. 2007. Strategi Pembelajaran Berorientasi Standar Proses Pendidikan. Jakarta : Kencana Prenada Media Group.

Sugiyono. 2013. Metode Penelitian Pendidikan. Alfabeta. Bandung.

Suyatno. 2009. Menjelajah Pembejaran Inovatif. Sidoarjo: Masmedia Buana Pustaka

Utomo, Edy Setiyo. 2016. "Pengaruh Model Pembelajaran Kooperatif Tipe Pair Check Terhadap Hasil Belajar Siswa". Jurnal Program Studi Pendidikan Matematika STKIP PGRI Jombang. (hIm.8-10). (diakses pada tanggal 4 Januari 2018).

Yantiani, Ni Md., I Wyn Wiarta, Md. Putra. 2013. Pembelajaran Kooperatif Pair Check Berpengaruh Terhadap Hasil Belajar Materi Bangun Ruang Dan Bangun Datar 
Siswa Kelas IV Gugus IV Semarapura. E-journal Pendidikan Guru Sekolah Dasar Vol 2 No 1

Yuliana, Nofita. (2014). Pembelajaran Kombinasi Tipe Pair Checks dan Peer Tutoring Mampu Meningkatkan Prestasi Belajar Akuntansi Siswa SMA. Jurnal Pendidikan. (Online). (http://jurnal.fkip.uns.ac.id/index.php/ekonomi/article.download/5269/372 3 di akses Kamis, 19 Februari 2017).

Yuliariska Febri. 2016. Penerapan Model Pair Check Untuk Meningkatkan Hasil Belajar Ipa Siswa Kelas IV. e-Journal PGSD Universitas Pendidikan Ganesha Jurusan PGSD Vol: 4 No: 1 Tahun: 2016.

Zaenab, Siti. 2017. Penerapan Model Pair Checks Untuk Meningkatkan Prestasi Belajar IPS Kelas VI. Jurnal Riset dan Konseptual Vol 2 No 3. 